\title{
Behaviour of Prunus cultivars and hybrids towards Agrobacterium tumefaciens estimated from hardwood cuttings
}

\author{
A Pierronnet ${ }^{\star}$, G Salesses
}

Unité de recherches sur les espèces fruitières et la vigne, Centre de Bordeaux, Inra, BP 81, F-33883 Villenave-d'Ornon cedex, France

(Received 5 July 1995; accepted 29 March 1996)

\begin{abstract}
Summary - Using the hardwood cuttings method, the behaviour of different Prunus spp, which can be used as rootstocks, was evaluated for susceptibility to the telluric bacteria Agrobacterium tumefaciens that induces crown gall. The results show that: i) for Prunus cerasifera all the clones studied are susceptible (among them the clone P2032 seems the least susceptible), and so are the different hybrids issued from crosses including $P$ cerasifera, except P2038 which is an hybrid between $P$ besseyi and $P$ cerasifera; ii) for Prunus domestica there is a low level of susceptibility among the clones and the hybrids issued from crosses including $P$ domestica. $P$ domestica seems interesting to use in breeding programs to introduce a low susceptibility to $A$ tumefaciens.
\end{abstract}

Agrobacterium tumefaciens / crown gall / Prunus / rootstock / susceptibility

Résumé - Comportement d'hybrides et de cultivars de Prunus, vis-à-vis d'Agrobacterium tumefaciens, estimé à partir de boutures ligneuses. En utilisant la méthode de boutures ligneuses, le comportement de différents Prunus, pouvant servir de porte-greffe, est étudié vis-à-vis de la bactérie tellurique Agrobacterium tumefaciens, microorganisme responsable de la galle du collet. Les résultats montrent que : i) pour les Prunus cerasifera, tous les clones étudiés sont sensibles (parmi eux, le clone P2032 semble le moins sensible) ainsi que les différents hybrides issus de croisements comportant $\mathrm{P}$ cerasifera, excepté le $\mathrm{P} 2038$ qui est un hybride entre $\mathrm{P}$ besseyi et $\mathrm{P}$ cerasifera ; ii) pour les Prunus domestica, le niveau de sensibilité est faible tant parmi les clones que parmi les hybrides ayant $\mathrm{P}$ domestica comme parent. P domestica apparaît intéressant à utiliser dans des plans de croisements, pour introduire une moindre sensibilité à A tumefaciens.

Agrobacterium tumefaciens / galle du collet / Prunus / porte-greffe / sensibilité

\section{INTRODUCTION}

Crown gall is a tumoric disease caused by a motile Gram-negative telluric Eubacterium: Agrobacterium radiobacter, Beijerinck and Van Delden, Conn pv tumefaciens, Smith and
Towsend (Kesters and De Ley, 1984) usually called Agrobacterium tumefaciens. Among the dicotyledons, a large number of species are susceptible, particularly in the Prunus genus (FaivreAmiot, 1982). Generally, the monocotyledons do not appear to be susceptible to $A$ tumefaciens

\footnotetext{
* Correspondence and reprints
} 
(Gautheret, 1980), though some reports mentioned the Agrobacterium-mediated cell transformation in some species of this class (Douglas et al, 1985; Hernalsteens et al, 1984; HooykaasVan Slogteren et al, 1984).

A tumefaciens is attracted to the exudates of wounded plant tissues (Shaw et al, 1988). It becomes pathogenic following attachment to the injured plant cells (Matthysse et al, 1981) and transfer of its Ti-plasmid T-DNA to the plant cell nuclear genome (Chilton et al, 1977). The T-DNA of virulent strains has an oncogenic region coding for products that upset the normal regulation of phytohormone synthesis in the plant cell and induce tumour growth by proliferation of the transformed cells (Tempé and Shell, 1987; Armitage et al, 1988). Large tumours generally weaken and may occasionally kill the plant (Faivre-Amiot, 1982).

Chemical control of this bacterium is inefficient, and disease prevention using $\mathrm{K} 84$ or K1026 strains of $A$ radiobacter var radiobacter are only efficient against susceptible strains of A tumefaciens (Kerr and Panagopoulos, 1977; Jones and Kerr, 1989; Ryder and Jones, 1991).

Therefore the identification of plant genetic variability for resistance to $A$ tumefaciens and its subsequent exploitation in breeding programmes, would be of significant agronomic value. This approach to the control of $A$ tumefaciens has been adopted previously for poplar (Nesme et al, 1990; Beneddra, 1990) and the first results, obtained with the hardwood cuttings method, that already had given a good estimation of the susceptibility of some different Prunus rootstocks (Pierronnet and Escalettes, 1990; Pierronnet and Eyquard, 1993) were encouraging enough to undertake this study with a larger number of different Prunus.

In the present study the objective was to identify possible sources of genetic resistance to $A$ tumefaciens in Prunus spp and their interspecific hybrids which could be of value in the rootstock breeding programme at the Unité de recherches sur les espèces fruitières et la vigne de Bordeaux. A first approach of the genetic determinism of resistance is undertaken.

\section{MATERIALS AND METHODS}

\section{Plant material}

The plant material consists of 87 Prunus of different genetic origins, representing eleven species as clones or as intraspecific or interspecific hybrids (table I). Its ploidy level varies from diploid $(2 n=16)$ to hexaploid $(2 n=48)$. Two hybrids issued from Damas de Toulouse are aneuploid because of the production, by the pentaploid Damas, of gametes with chromosomes number varying from 16 to 24. According to Salesses (1977) Damas de Toulouse is an interspecific hybrid: $P$ domestica (or $P$ insititia) $\times P$ spinosa. The different ploidy levels of the Marianna plum descendants, P8-1 (triploid), P8-13 and P10-2 (both pentaploid) could be explained, first by interspecific hybridization, second by the production of polyploid gametes by the diploid Marianna plum. So, P8-1 is probably issued from a cross between Marianna plum and $P$ cerasifera (Salesses, 1977) whereas P10-2 and P8-13 could originate from crosses between Marianna plum and a hexaploid plum $P$ domestica or $P$ insititia (Bernhard, personal communication).

This material is under evaluation or already used as rootstock (table VI).

\section{Bacterial material}

Strain AT 78A025 of $A$ tumefaciens was isolated from infected Prunus persica L by Faivre-Amiot (personal communication). It is a nopaline strain which has a well established aggressiveness towards the Prunus genus.

Bacteria were cultured on a potato medium containing $20 \mathrm{~g}$ of sucrose, $20 \mathrm{~g}$ of agar-agar, $5 \mathrm{~g}$ of $\mathrm{NaCl}$, $500 \mathrm{~mL}$ of water in which $200 \mathrm{~g}$ of peeled potatoes were boiled for 20 minutes, and $500 \mathrm{~mL}$ of distilled water. Bacterial cultures were incubated at $20^{\circ} \mathrm{C}$ for four days and then used for the inoculation of Prunus cuttings at a concentration $>10^{8} \mathrm{cfu} / \mathrm{mL}$.

\section{Auxin solution}

A solution of indolbutyric acid (IBA) was prepared by dissolving $200 \mathrm{mg}$ of IBA in $30 \mathrm{~mL}$ of ethanol and then diluting to a final volume of $100 \mathrm{~mL}$ with distilled water (ie, $2000 \mu \mathrm{g} I \mathrm{BA} / \mathrm{mL}$ ).

\section{Inoculation of plant material}

Hardwood cuttings of $15-\mathrm{cm}$ length were harvested from the orchard following leaf fall (November). Sixty cuttings were selected for each clone, progeny or hybrid, and were stored in polyethylene bags for about one month in a cold room $\left(4{ }^{\circ} \mathrm{C}\right.$ at $100 \%$ relative humidity).

At the beginning of December, after recutting the basal end to make a fresh wound, the cuttings were inoculated by dipping the base in the bacterial suspension or in auxin solution for the control. The IBA treated cuttings were only used as a control of the plant material viability during the experiment. For each treatment, 30 cuttings were used. 
Table I. Origin, clone number, and chromosome number of the 87 evaluated Prunus.

Genetic origin

$P$ besseyi

$P$ besseyix $P$ cerasifera

$P$ besseyix $P$ cerasifera

$P$ besseyix $P$ persica

$P$ cerasifera

$P$ cerasifera

$P$ cerasifera

$P$ cerasifera

$P$ cerasifera

$P$ cerasifera

$P$ cerasifera

$P$ cerasifera $x$ cerasifera

$P$ cerasifera $\times$ cerasifera

$P$ cerasifera $\times P$ cerasifera

$P$ cerasifera $\times$ cerasifera

$P$ cerasifera $\times(P$ cerasifera $x$ Japanese plum)

$P$ cerasifera $x$ Japanese plum

Damas de Toulouse

Damas de Toulouse self pollination

Damas de Toulouse $\times \mathrm{P}$ domestica

$P$ dasycarpa

$P$ domestica $\times P$ cerasifera

$P$ domestica $\times P$ cerasifera

$P$ domestica $\times P$ domestica

$P$ domestica $\times P$ spinosa

$P$ domestica $\times P$ spinosa

$P$ domestica $\times$ Japanese plum

$P$ insititia $\times P$ domestica

$P$ insititia (Saint-Julien-d'Orléans) progeny

$P$ insititia (Saint-Julien-d'Orléans) progeny

Japanese plum $\times(P$ cerasifera $\times$ Japanese plum)

Japanese plum $\times(P$ cerasifera $\times P$ persica $)$

Japanese plum $\times P$ persica

Japanese plum $\times P$ spinosa

Marianna plum

Marianna plum progeny

Marianna plum progeny

Marianna plum progeny

$P$ persica $x$ davidiana

$P$ spinosa $\times P$ cerasifera

$P$ spinosa $\times P$ domestica
Number of clone or hybrid

$2 n$

P3495 16

P2037 16

P2038 16

P3400 16

P18 16

P1079 16

P1090 16

P1254 16

P2032 16

P2175 16

P2980 16

$P(2175 \times 2032)$ ( 9 hybrids) $\quad 16$

$P(2032 \times 2175)$ (10 hybrids) 16

$P(2175 \times 1079)$ (16 hybrids) 16

$P(2032 \times 1079)$ (15 hybrids) 16

$P[1079 \times(16-5 \times 2128) 2] 21 \quad 16$

$P(16-5 \times 2128) 2 \quad 16$

P1869 40

P1869-4 41

$P(1869 \times 328) 48$

P2315 16

$P(2036 \times 1079) 2$

$P(2036 \times 16-5) 3 \quad 32$

P3116 48

$P(253 \times 106) 77 \quad 40$

$P(707 \times 55) 16$

$P(2036 \times 2069) 2$

P3295 48

St Julien 58-7 40

St Julien GF 655-2 48

$P[2128 \times(16-5 \times 2128) 2] 16 \quad 16$

P3293 16

P3294 16

P3297 32

P2736 16

P8-1 . 24

P8-13 40

P10-2 40

P3296 (P41-4-21) 16

$\mathrm{P}(106 \times 2175) 5$

$\mathrm{P}(33-0 \times 1249) 17 \quad 40$

$\mathrm{p}=$ Plum or prune; $\mathrm{S}=$ peach; $\mathrm{SJ}=$ Saint-Julien-d'Orléans; $\mathrm{Sp}=$ Prunus spinosa; progeny = obtained from open pollination; P18 = clone of Myrobalan B; P213 = cv Pershore; P253 = cv Reine-Claude d'Althan; P322 = cv Belsiana $(P$ cerasifera $\times P$ triflora $)$ (Bernhard, 1962); P328 = cv Mme Guttin; P707 = clone of French prune (Prune d'Ente); P871 = $P$ cerasifera $\times P$ persica; $\mathrm{P} 1249=\mathrm{cv}$ Krasinsky; P1869 = Damas de Toulouse $[P$ domestica (or $P$ insititia) $\times P$ spinosa (Salesses, 1977); P2036 = cv Stanley; P2069 = cv Methley ( $P$ cerasifera $\times P$ salicina) (Day and Tufts, 1944); P2128 = cv Burbank (seedling imported from Japan by Burbank); P2736 = Marianna plum (issued from $P$ cerasifera and $P$ munsoniana, Salesses, 1977); P3116 = Reine-Claude vraie P994 $\times$ ReineClaude d'Althan P148; P3293 = P322 x P871; P3294 = P322 x S1058; P3295 = SJ53 x P213; P3296 = $P$ persica $\times P$ davidiana (cv Avimag-Cadaman); P3297 = P2069 x Sp106; S 1058 = cv Yunnan. 
After drying, the cuttings were packed in polyethylene bags and stored for 20 days at room temperature (approximately $20^{\circ} \mathrm{C}$ ) in the dark to initiate either gall (treated cuttings) or callus (control cuttings) formation.

All cuttings were then put in containers under favourable conditions for rooting, ie, with moderate watering, in a cool greenhouse with the basal ends placed into a gravel/sand mixture (50:50).

\section{Calculation}

After three months, the diameter $(D)$ of the galls induced by $A$ tumefaciens and the diameter $(d)$ of the cuttings just above the gall were measured. The difference was then calculated for each cutting as $\Delta=D-$ $d$ and the mean ' $\Delta$ ' of 30 replicates calculated.

An analysis of variance was carried out on the data using Amance software (INRA, Centre de Nancy) and the Bonferroni test was used to calculate significant differences between the clones or hybrids responses to A tumefaciens infection.

As there is no reference material for behaviour visà-vis this extant disease and in order to give some insight on the ranking of the various genotypes in this study, we have used Bonferroni's multiple comparison test following an analysis of variance in order to tentatively distinguish groups, in spite of the shortcomings of such a procedure.

\section{RESULTS}

\section{P cerasifera clones and their hybrids}

P2032, P1079 and 15 hybrids obtained from these two genotypes (P2032 used as female) were evaluated for their behaviour towards $A$ tumefaciens. The results, summarized in table II, show that P2032 is significantly less susceptible than P1079 and their hybrids. Most of the hybrids $\mathrm{P}(2032 \times 1079)$ are as susceptible as P1079 and three hybrids (16 - $38-14)$ are more susceptible.

$\mathrm{P} 1079$ was also used as male parent in a cross with the $P$ cerasifera clone P2175. The two parents and 16 hybrids, were evaluated for their behaviour towards $A$ tumefaciens (table III).

As in the previous cross we can observe a high level of susceptibility.

The results show that there is no significant difference between P2175, P1079 and ten of their hybrids whereas six and three hybrids are respectively more susceptible than P2175 and than $\mathrm{P} 1079$.

If we compare the susceptibility of these two series of hybrids obtained using P1079 as male parent (fig 1), we can observe a predominant

Table II. Response to A tumefaciens of two Prunus cerasifera clones, P2032 and P1079, and their hybrids.

Clone or hybrid no

\section{P2032}

$\mathrm{P}(2032 \times 1079) 23$

$P(2032 \times 1079) 21$

$P(2032 \times 1079) 3$

$\mathrm{P}(2032 \times 1079) 6$

P1079

$\mathrm{P}(2032 \times 1079) 36$

$\mathrm{P}(2032 \times 1079) 33$

$P(2032 \times 1079) 24$

$\mathrm{P}(2032 \times 1079) 18$

$P(2032 \times 1079) 32$

$\mathrm{P}(2032 \times 1079) 12$

$\mathrm{P}(2032 \times 1079) 13$

$P(2032 \times 1079) 27$

$\mathrm{P}(2032 \times 1079) 16$

$\mathrm{P}(2032 \times 1079) 38$

$\mathrm{P}(2032 \times 1079) 14$ $\checkmark \mathrm{\prime}(\mathrm{mm})$

Groups of ' $\Delta$ '

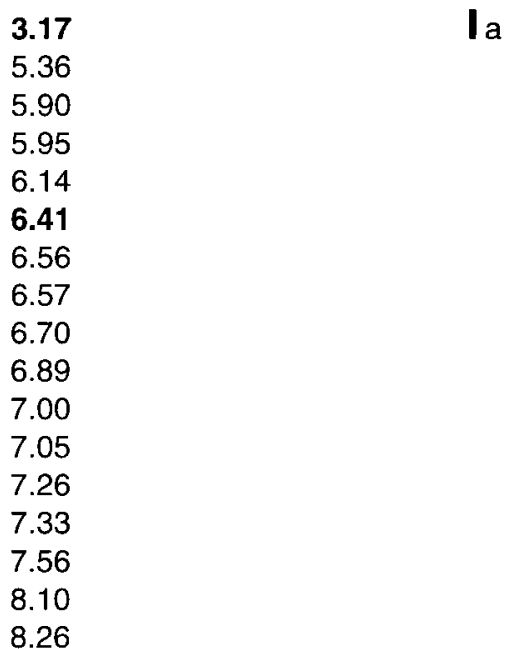

Ia

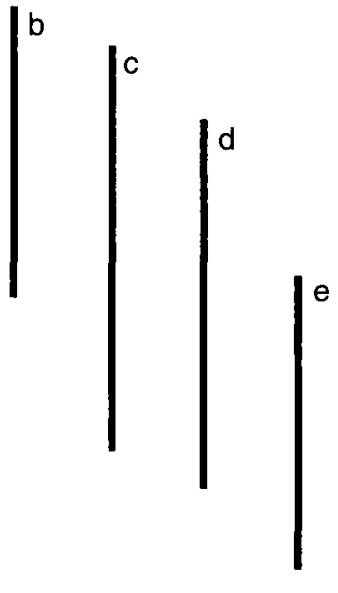


Table III. Response to A tumefaciens of two Prunus cerasifera clones, P2175 and P1079, and of their hybrids.

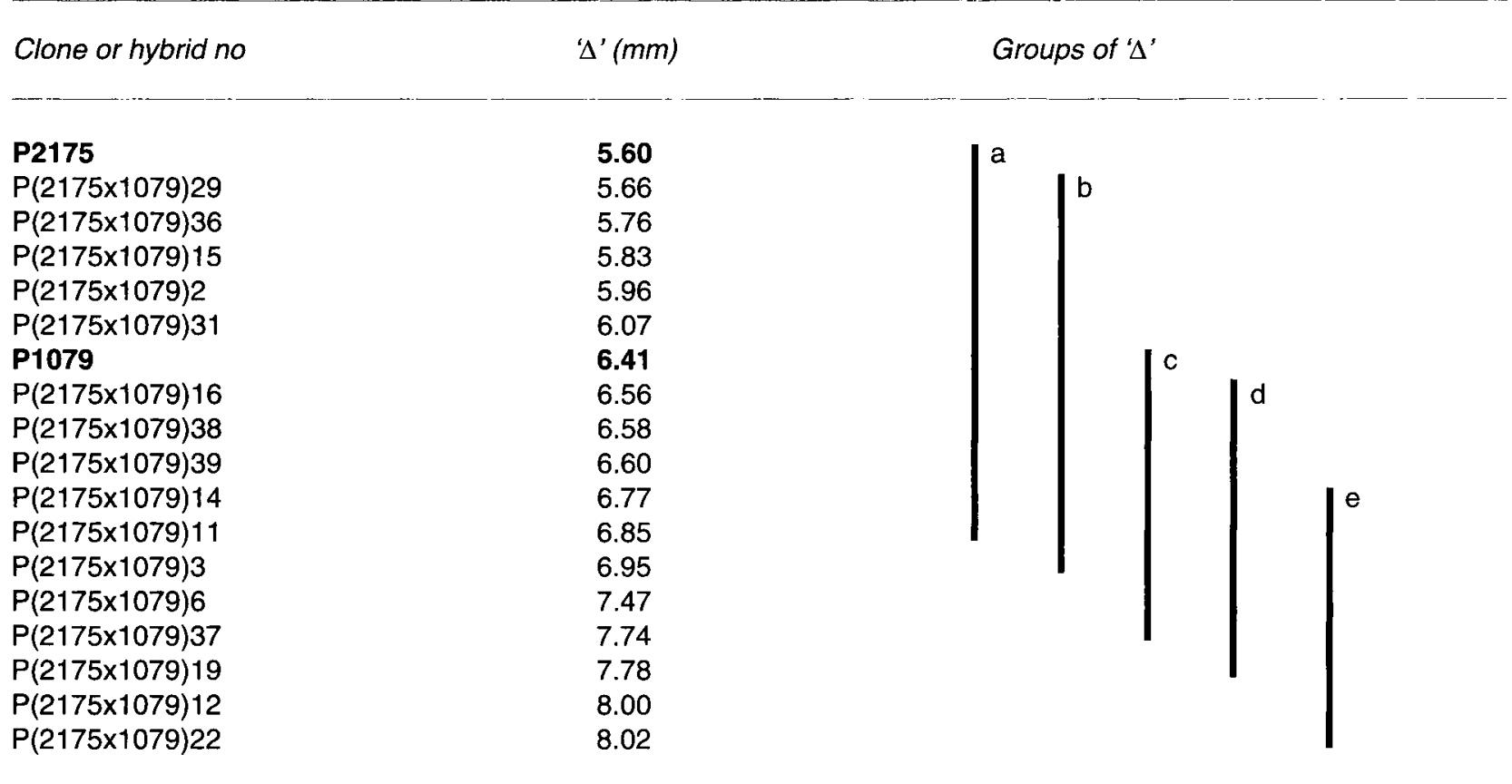

The statistically significant difference of the groups was established at the probability level $p=0.05$.

effect of the most susceptible parent P1079. The hybrids are grouped around $\mathrm{P} 1079$ and no hybrid presents the same low level of susceptibility as P2032.

In the case of $\mathrm{P} 2032$ and $\mathrm{P} 2175$, reciprocal hybrids were available. Nine $P(2175 \times 2032)$ hybrids and ten $\mathrm{P}(2032 \times 2175)$ hybrids were simultaneously tested comparatively to their parents (table IV).

Among the hybrids issued from the clone P2032, only one, (-12), issued from P2032 used as male parent, shows the same behaviour as P2032, while the others are significantly more susceptible. This hybrid $(-12)$ is significantly less susceptible than P2175. Among the others, fifteen hybrids, $(-49)$ to $(-24)$, are as susceptible as P2175 and three are more susceptible; among the former, eight have P2032 as male parent and seven as female parent. It is worth noting that the most susceptible group of hybrids (group $h$ ) is composed exclusively of six hybrids issued from P2032 used as female parent.

The comparison between the overall mean [' $\Delta$ '] of the $P(2175 \times 2032)$ hybrids and that of the $P(2032 \times 2175)$ hybrids shows a significant difference at $p=0.02$. The $\mathrm{P}(2175 \times 2032)$ family, with $\left[{ }^{\prime} \Delta^{\prime}\right]=5.35$, is significantly less susceptible than the $\mathrm{P}(2032 \times 2175)$ family with [' $\Delta$ '] $=6.29$.
Fig 1. Distribution of the hybrids $P(2175 \times 1079)$ and $P(2032 \times$ 1079) for ' $\Delta$ '.

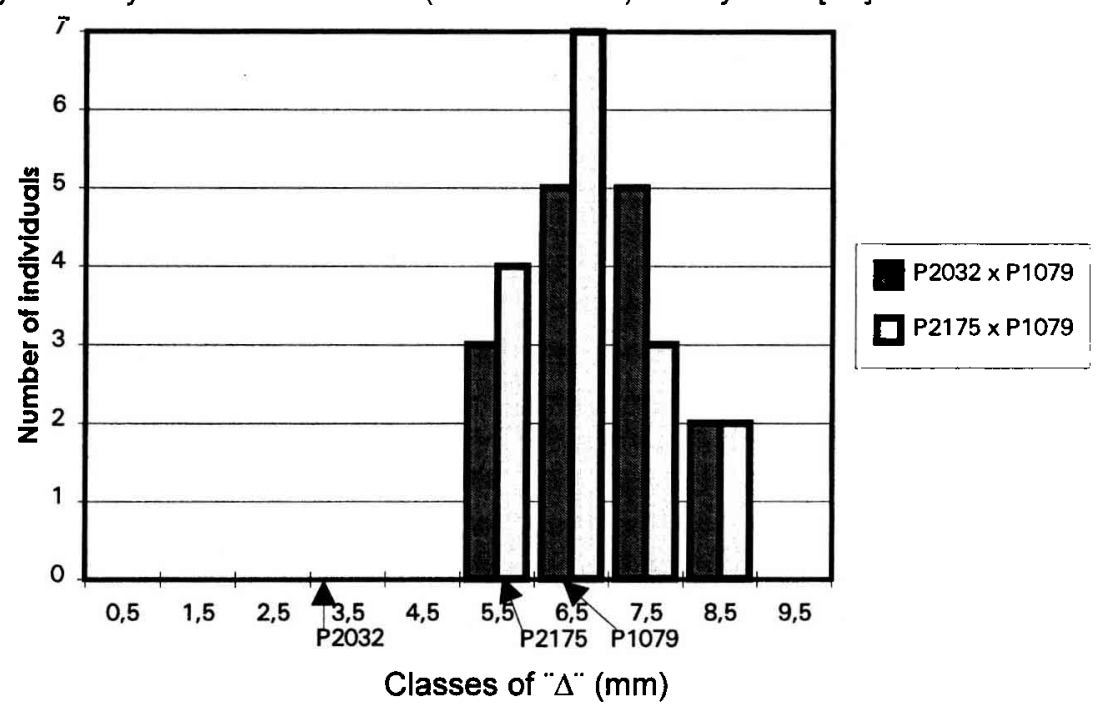


Table IV. Response to A tumefaciens of two Prunus cerasifera clones, P2032 and P2175, and their hybrids from reciprocal crosses.

Clone or hybrid no

\begin{tabular}{ll}
\hline$P 2032$ & 3.17 \\
$P(2175 \times 2032) 12$ & 3.65 \\
$P(2032 \times 2175) 49$ & 4.72 \\
$P(2175 \times 2032) 7$ & 4.80 \\
$P(2032 \times 2175) 11$ & 5.19 \\
$P(2175 \times 2032) 9$ & 5.21 \\
$P(2175 \times 2032) 27$ & 5.31 \\
$P 2175$ & 5.60 \\
$P(2175 \times 2032) 1$ & 5.66 \\
$P(2175 \times 2032) 25$ & 5.69 \\
$P(2175 \times 2032) 33$ & 5.83 \\
$P(2032 \times 2175) 27$ & 5.88 \\
$P(2175 \times 2032) 30$ & 5.93 \\
$P(2032 \times 2175) 52$ & 6.04 \\
$P(2175 \times 2032) 16$ & 6.08 \\
$P(2032 \times 2175) 54$ & 6.24 \\
$P(2032 \times 2175) 47$ & 6.36 \\
$P(2032 \times 2175) 24$ & 6.71 \\
$P(2032 \times 2175) 38$ & 7.11 \\
$P(2032 \times 2175) 4$ & 7.13 \\
$P(2032 \times 2175) 10$ & 7.58 \\
& \\
\hline & \\
The statistically significant difference of the groups was establis & \\
& \\
The distribution for ' $\Delta$ ' of reciprocal hybrids \\
and their parents (fig 2) shows a difference in \\
susceptibility between the hybrids issued from \\
both crosses according to the direction of the \\
cross between the two parents.
\end{tabular}

\section{Prunus spp and interspecific hybrids}

The behaviour of eleven Prunus species, and different interspecific hybrids, is presented in table $V$ and illustrated in figure 3.

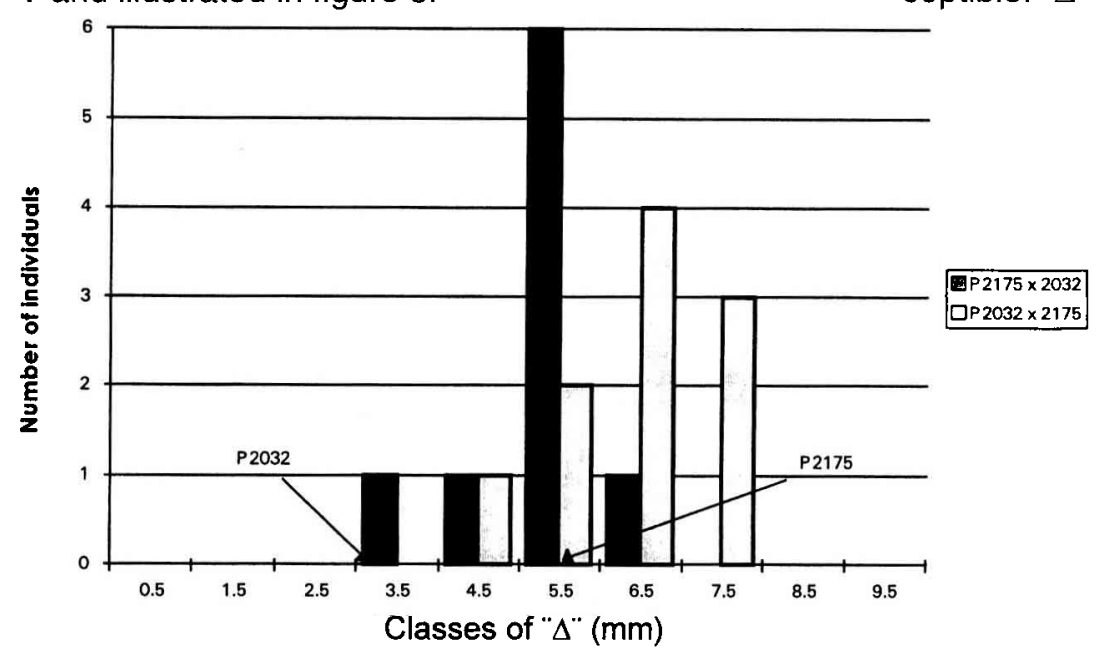

Table $V$ and figure 3 show that there is a large variability of the behaviour according to genetic origin (classes from 0.5 to 7.5 ). We can consider that there are two levels of susceptibility in the tested Prunus estimated by the ' $\Delta$ ' value. The ' $\Delta$ ' range $0-3$, corresponds to the least susceptible, while the ' $\Delta$ ' ranges $3-8$ groups the susceptible clones or hybrids.

The data analysis of table $V$ shows that $P$ domestica (D) and its progenies display interesting behaviour and are among the least susceptible: ' $\Delta$ ' $<1.5$ and ' $\Delta$ ' $<3$ for five and nine,
Fig 2. Distribution of the hybrids compared with P2175 and P2032 for ' $\Delta$ '. 
respectively, out of 11 individuals having $P$ domestica as parent. Most of the hybrids issued from $P$ domestica show a rather good behaviour and the two hybrids with a $P$ domesti$c a$ as a parent and giving a value of ' $\Delta$ ' $>4.5$, ie, $P(2036 \times 1079) 2$ and $P(2036 \times 16-5) 3$, have $P$ cerasifera, $\mathrm{P} 1079$ and $\mathrm{P} 16-5$ respectively, both showing the same level of susceptibility (Pierronnet, unpublished data) as second parent.

The majority of $P$ cerasifera clones and their progeny have a value of ' $\Delta$ ' $>3$ and the clones P2980 and P2032 appear as the less susceptible (respectively ' $\Delta$ ' $=2.74$ and 3.17 ) among the tested individuals of this species.

$P$ spinosa and the Japanese plum, used in this work, seem to have no significant effect on the hybrid susceptibility when hybridized with either $P$ domestica (moderately susceptible) or $P$ cerasifera (relatively susceptible).

P3495, the only clone of $P$ besseyi evaluated, is among the least susceptible (' $\Delta$ ' $=2.50$ ). Two hybrids issued from a natural cross between a same $P$ besseyi and $P$ cerasifera were evaluat-

Table V. Behaviour of different species and hybrids of Prunus.

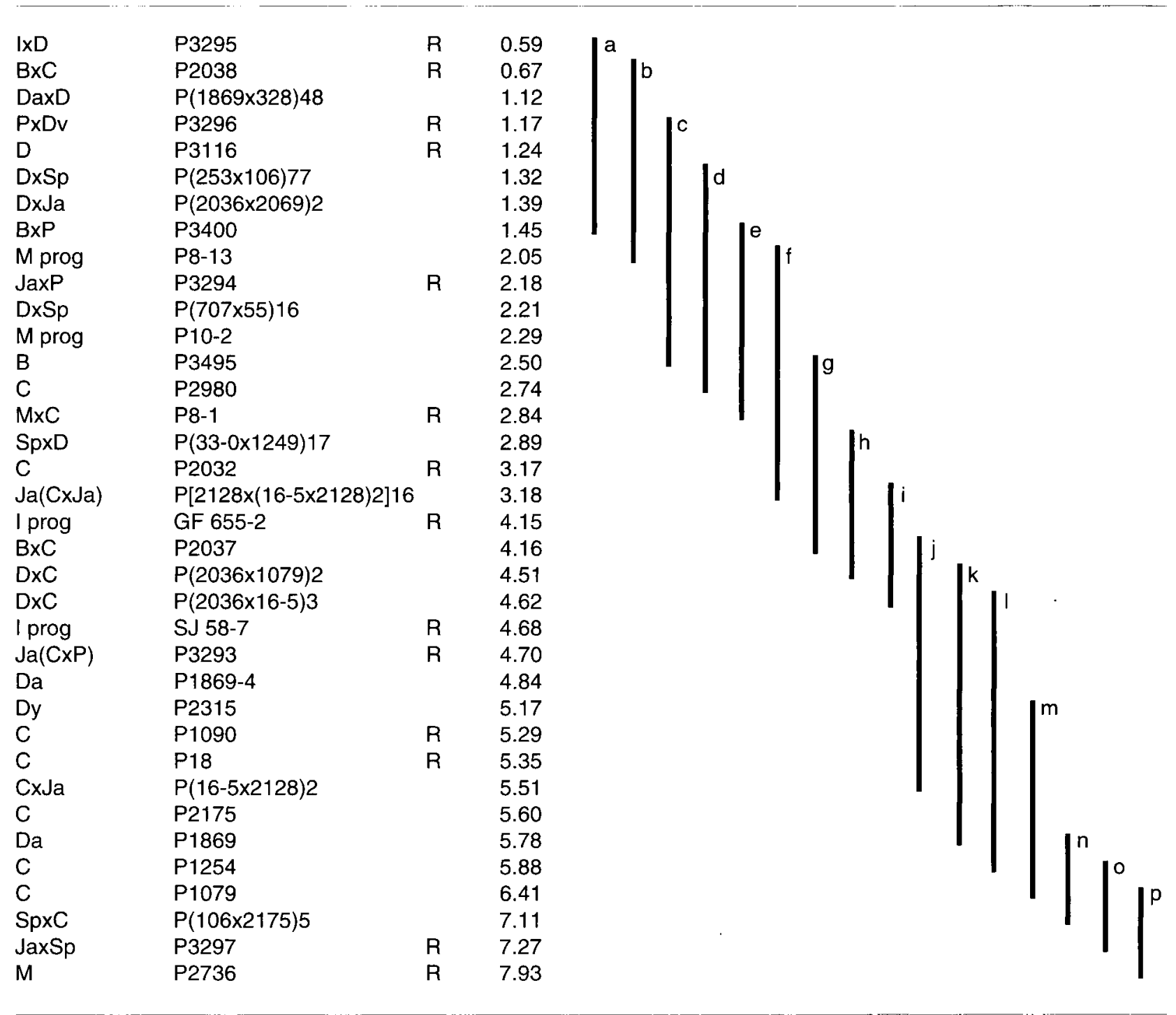

The statistically significant difference of the groups was established at the probability level $p=0.05$. List of abbreviations for the genetic origin. $\mathrm{B}=P$ bessey; $\mathrm{C}=P$ cerasifera; $\mathrm{D}=P$ domestica; $\mathrm{Da}=$ Damas; $\mathrm{Dv}=P$ davidiana; $\mathrm{Dy}=P$ dasycarpa; $\mathrm{I}=P$ insititia; $\mathrm{Ja}=$ Japanese plum; $\mathrm{M}=$ Marianna plum; $\mathrm{p}=P$ persica; $\mathrm{Sp}=P$ spinosa. $\mathrm{R}=$ already used as rootstocks; $p$ rog $=$ seed obtained from open pollination. 


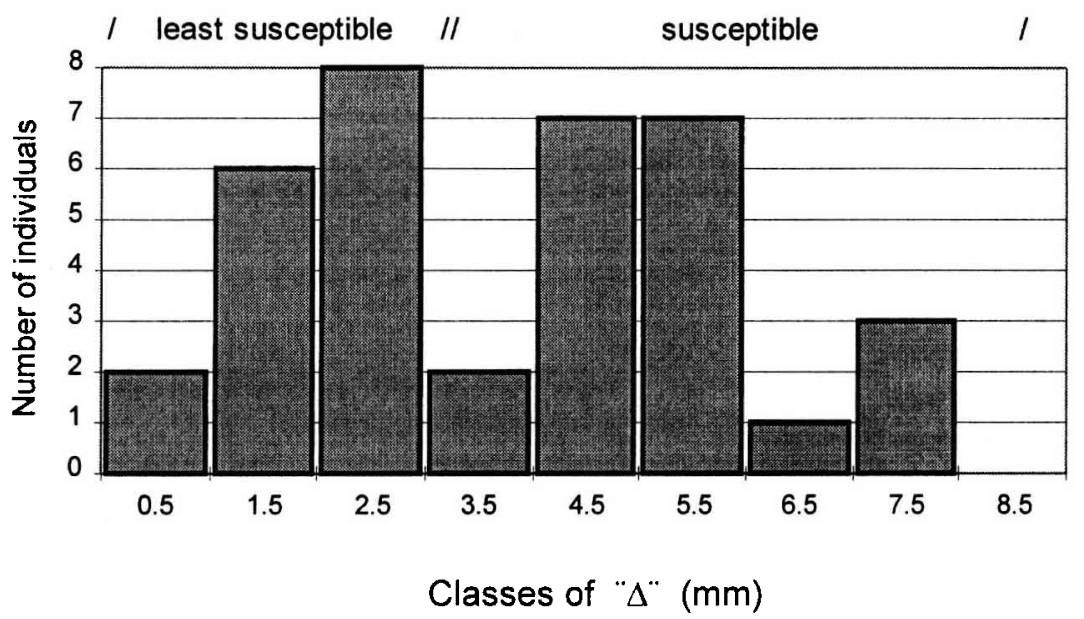

Fig 3. Distribution for ' $\Delta$ ' of all the Prunus, clones or hybrids, evaluated towards $A$ tumefaciens.

ed: one, P2038, shows a good behaviour (' $\Delta$ ' $=0.67$ ), whereas the second appears susceptible (' $\Delta$ ' $=4.15)$.

The Marianna plum clone P2736 is very susceptible but we observe the low susceptibility of P8-13 and P10-2, both pentaploid hybrids obtained from open pollination of Marianna plum, likely by an hexaploid Prunus, $P$ domestica or $P$ insititia; (P8 and P10 are two numbers of clone from the same mother-tree of Marianna plum, Bernhard, personal communication).

Damas de Toulouse P1869, P1869-4 (issued from a self pollination of $\mathrm{P} 1869$ ), and the clone P2315 of $P$ dasycarpa which is originating from a cross between $P$ armeniaca and $P$ cerasifera (Rehder, 1940), are susceptible.
In this study the behaviour of 13 rootstock clones, selected at INRA and registered into the French official Catalogue des espèces et variétés, was investigated (table VI). These rootstocks were identified as moderately susceptible (five clones) or susceptible (eight clones).

The results for Avimag (clone P3296) shown in table $V$ are not valid due to excessive gall necrosis caused by prolonged contact with overmoist sand. In previous experiments, P3296 was found to be susceptible (Pierronnet, unpublished data).

\section{DISCUSSION}

The entire wounding of the cambium ring, the use of a very concentrated bacterial suspension

Table VI. Response to A tumefaciens of the 13 registered Prunus rootstocks.

\begin{tabular}{|c|c|c|c|c|}
\hline Clone name & Clone no & Trademark & Genetic origin & Behaviour \\
\hline Ferdor & P3295 & Julior@ & $P$ insititia $\times P$ domestica & mod suscep \\
\hline Ferlenain & P2038 & Plumina $®$ & $P$ besseyi $\times P$ cerasifera & mod suscep \\
\hline Avifel & P3116 & Torinel® & $P$ domestica $\times P$ domestica & mod suscep \\
\hline Yumir & P3294 & Myran® & Japanese plum $\times$ P persica & mod suscep \\
\hline GF 8-1 & P8-1 & & Marianna plum $\times P$ cerasifera & mod suscep \\
\hline Myrest & P2032 & Myrabiß & $P$ cerasifera & susceptible \\
\hline Saint-Julien & GF 655-2 & & $P$ insititia progeny & susceptible \\
\hline Fercien & SJ 58-7 & & $P$ insititia progeny & susceptible \\
\hline Ferciana & P3293 & Isthara ( & Japanese plum $\times(P$ cerasifera $\times P$ persica $)$ & susceptible \\
\hline Fercino & P1090 & Myrocal $\circledast$ & $P$ cerasifera & susceptible \\
\hline GF 1869 & P1869 & & Damas de Toulouse & susceptible \\
\hline Fereley & P3297 & Jaspi@ & Japanese plum $\times$ P spinosa & susceptible \\
\hline Avimag & P3296 & Cadaman $(\mathbb{B}$ & $P$ persica $\times P$ davidiana & susceptible \\
\hline
\end{tabular}


for inoculation, and the calculation of ' $\Delta$ ' issued from 30 cuttings are factors which minimize the risk of having, like Cardenas (1975), difficulty in interpretation of the results due to gall size variation. The control of cultural conditions in the greenhouse allows the obtention of more homogeneous results than those obtained outdoor, by us (Pierronnet, unpublished data) or by Nesme et al (1990) on poplar.

The results obtained confirm numerous observations made under orchard or nursery conditions, as well as data published by Smith (1925) and those obtained more recently by Pierronnet and Escalettes (1990) and Pierronnet and Eyquard (1993). The relatively high and low susceptibilities of $P$ cerasifera and $P$ domestica respectively were already observed in 1925, although Smith mentioned some variability within the $P$ domestica group.

Within the $P$ cerasifera species, P2980 and P2032 are the least susceptible clones. For the hybrids used in this experiment, raised from P2032, no inheritance of this low susceptibility can be seen. On the contrary, there is a higher susceptibility in all the hybrids compared to P2032 (except the -12), and for 13 out of 19 hybrids compared to $\mathrm{P} 2175$, particularly for the hybrids P2032 $\times$ P2175. It is worth noting that, in hybrids involving P2032 and P2175, P2032 confers a greater susceptibility when used as female parent. The existence of a maternal effect exerted by $\mathrm{P} 2032$ for higher susceptibility remains to be confirmed. To test the validity of this observation, further work using a larger number of hybrids is necessary.

In interspecific crosses, the few hybrids of $P$ cerasifera used in combination with either $P$ spinosa, Japanese plums or $P$ domestica $\mathrm{cv}$ Stanley clone P2036 are susceptible. On the other hand, the results for $P$ domestica show that for this species there is a tendency towards a low susceptibility. This characteristic could be transmitted to the few hybrids tested, issued from crosses between $P$ domestica and other species such as $P$ spinosa, Marianna plum or the Japanese plums.

In the case of crosses between $P$ domestica cv Stanley, previously evaluated and found moderately susceptible, and $P$ cerasifera $\mathrm{P} 1079$ or $\mathrm{P} 16-5$, the hybrids obtained have a susceptibility which is intermediate to that of the parents. P165 has been found to be as susceptible as P1079 in a previous investigation (Pierronnet, unpublished data).
The behaviour of the tested clone of $P$ besseyi is equivalent to that of the least susceptible $P$ cerasifera (P2032 and P2980) and the susceptibilities of two sibling hybrids issued from the cross of one $P$ besseyi with $P$ cerasifera are very different: P2037 is susceptible and P2038 may be considered as resistant. We can only note the good behaviour of P2038, confirming a previous observation (Pierronnet and Escalettes, 1990).

The experimental conditions, previously described for investigating susceptibility to $A$ tumefaciens, require specific conditions necessary to get reliable responses. Particular attention should be paid to temperature management and to sand moisture level since frost or root asphyxia can easily cause necrosis of the tissues developing during the period of gall swelling.

The use of only one strain of $A$ tumefaciens may be criticized. In a first step only the strain AT 78 A025, which was previously isolated from the experimental site, and evaluated in numerous occasions as very aggressive, was chosen. The introduction of other potentially aggressive strains of Agrobacterium into the experiments must be taken into account but at this time their utilization in the experimental site for in vivo experiments was considered undesirable.

With the exception of two clones (P1090, $P 1869)$, the results obtained from this in vivo experiment were in agreement with those obtained from an in vitro experiment (Pierronnet and Escalettes, 1990) for the appreciation of the susceptibility. This agreement needs to be reexamined since in vitro experimentation offers the advantage of working with several aggressive bacterial strains.

\section{CONCLUSION}

Our previous observations, carried out in orchard or nursery, have pointed out the susceptibility of different Prunus rootstocks to $A$ radiobacter $\mathrm{pv}$ tumefaciens.

The present study, using the previously described cuttings method as an easy early test of selection, indicates tendency to susceptibility for Prunus cerasifera and to low susceptibility for Prunus domestica. It is possible to use genitors belonging to this species in a breeding programme which includes crown gall resistance as one of the selection criteria, in order to get rootstocks presenting a good low level of susceptibility to this pest. 


\section{ACKNOWLEDGMENTS}

We thank JP Eyquard for his technical collaboration and $\mathrm{A}$ Bonnet for his assistance in the greenhouse.

\section{REFERENCES}

Armitage P, Walden R, Draper J (1988) Vectors for transformation of plant cells using Agrobacterium. In: Plant Genetic Transformation and Gene Expression. A Laboratory Manual (J Draper, R Scott, P Armitage, R Walden, eds), Blackwell Scientific Publication, Oxford, UK, 1-67

Beneddra T (1990) Étude de la sensibilité d'hybrides Populus tremula $L \times$ Populus alba $L$ à Agrobacterium tumefaciens (Smith \& Townsend) Conn, l'agent causal du crown gall. Thesis, Institut national agronomique Paris-Grignon

Bernhard R (1962) Les hybrides prunier x pêcher et prunier $x$ amandier : principales caractéristiques, comportement comme porte-greffe éventuels du pêcher. In: Advances in Horticultural Science and their Applications 2 (JC Garnaud, ed), Pergamon Press, Oxford, 74-86

Cardenas RA (1975) Étude de la maladie du crown gall et de son agent pathogène Agrobacterium tumefaciens (Smith et Townsend) Conn chez divers porte-greffes des arbres fruitiers à noyaux. Thesis, Université de Bordeaux 1

Chilton MD, Drummond MH, Merlo DJ, Sciaky D, Montoya AL, Gordon MP, Nester EW (1977) Stable incorporation of plasmid DNA into higher plants cells: the molecular basis of crown gall tumorigenesis. Cell 11, 263-271

Day LH, Tufts WP (1944) Nematods-resistant rootstocks for deciduous fruit trees. Circular of Californian Agricultural Experimental Station 359, $16 \mathrm{p}$

Douglas C, Halperin W, Gordon M, Nester E (1985) Specific attachment of Agrobacterium tumefaciens to Bamboo cells in suspension cultures. $J$ Bacteriol $161,764-766$

Faivre-Amiot A (1982) La galle du collet ou tumeur à Agrobacterium tumefaciens. Phytoma Def Veg 341, 33-36

Gautheret MR (1980) Exposés sur le cancer. La transformation tumorale de la cellule végétale. Cr Acad Sci Sér III : Sci Vie 290, 31-47 (supplément à la Vie académique, juin 1980)
Hernalsteens JP, Toong T, Schell J, Van Montagu M (1984) An Agrobacterium-transformed cell culture from the monocot Asparagus officinalis. EMBO J 3 , 3039-3041

Hooykaas-Van Slogteren GMS, Hooykaas PJJ, Schilperoort RA (1984) Expression of Ti plasmid genes in monocotyledonous plants infected with Agrobacterium tumefaciens. Nature (Lond) 311 , 763-764

Jones DA, Kerr A (1989) Agrobacterium radiobacter strain K1026, a genetically engineered derivate of strain K84, for biological control of crown gall. Plant Dis 73, 15-18

Kerr A, Panagopoulos CG (1977) Biotypes of Agrobacterium radiobacter var tumefaciens and their biological control. Phytopathol Z90, 172-179

Kesters K, De Ley J (1984) Agrobacterium. In: Bergey's Manual of Systematic Bacteriology 1 (NR Krieg, Williams, Wilkins, eds), Baltimore, 244-254

Matthysse AG, Holmes KV, Gurlitz RHG (1981) Elaboration of cellulose fibrils by Agrobacterium tumefaciens during attachment to carrot cells. $J$ Bacteriol 145, 583-595

Nesme X, Beneddra T, Collin E (1990) Importance du crown gall chez les hybrides Populus tremula $\mathrm{L} \times$ $P$ alba $\mathrm{L}$ en pépinière forestière. agronomie 10 , 581-588

Pierronnet A, Escalettes V (1990) Study of the behaviour of Prunus cultivars towards Agrobacterium radiobacter var tumefaciens. Acta Hortic 283, 327332

Pierronnet A, Eyquard JP (1993) Prunus porte-greffe et galle du collet. Sélection et protection par Agrobacterium radiobacter. Arboric fruit 466, 37-41

Rehder A (1940) Rosaceae. In: Manual of Cultivated Trees and Shrubs. The Macmillan Company, New York, 462-463

Ryder MH, Jones DA (1991) Biological control of crown gall using Agrobacterium strains K84 and K1026. Austr J Plant Physiolog 18, 571-579

Salesses G (1977) Recherches sur l'origine de deux pruniers porte-greffe hybrides interspécifiques naturels : un exemple d'étude cytologique développée pour la création de porte-greffe nouveaux chez les pruniers. Ann Amélior Plant 27, 235-243

Shaw CH, Ashby AM, Loake GJ, Watson MD (1988) One small step: the missing link in crown gall. Oxf Surv Plant Mol Cell Biol 5, 177-183

Smith CO (1925) Crown-gall studies of resistant stocks for Prunus. J Agric Res 31, 957-971

Tempé J, Schell J (1987) La manipulation des plantes. La Recherche 188, 696-709 